\title{
An Efficient Technical Solution or an Ideologically Contested Approach - the balance sheet for business style accrual accounting in the public sector
}

Andy Wynne

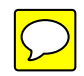

andywynne@lineone.net

\section{Abstract}

This paper briefly outlines why business style accrual accounting is not generally appropriate for the public sector, but that this idea is not a recent development. It then goes on to consider the actual evidence for the costs and benefits of business style accrual accounting in the UK, Australia and New Zealand. It also reviews the significant problems of implementation in the Cayman Islands. The paper concludes that recent events have led to a greater questioning of New Public Management and so the possible value of business style accrual accounting for the public sector. This provides the incentive to develop existing approaches to public sector financial reporting in ways which recognize the distinctive objectives and nature of government in the provision of public goods and services.

\section{Introduction}

In recent years there has been a sustained argument from the International Federation of Accountants (IFAC), national professional accounting associations, the OECD, World Bank, IMF and others for governments around the world to follow the lead of Australia, New Zealand and the UK and introduce business style accrual accounting as the basis for government financial reporting (Smullen 2009). The claim is that this approach will provide more useful information and so enable governments to be managed more efficiently.

However, this belief is based more on the ideologically contested view that governments should be run like a business than the actual experience of using business style accrual accounting over the last couple of decades. So, for example, the then chair of IFAC's public sector committee argued that a government "is no more than a huge business" and, therefore that the government's financial reports should be similar to those in the private sector (Anon, 2003).

Since the late 1980s a variety of approaches, termed New Public Management, have been considered international best practice. This has emphasised the importance of efficiency and the claim that this will be increased if governments work more like business (Hood 1991; Pollitt \& Bouckaert 2000). Alongside a range of other public management reforms, such as contracting out and the creation of agencies, business style accrual accounting has been advocated as the best model for governments to report on their finances (Guthrie, Humphrey, Jones \& Olson 2005; Smullen 2009).

The actual level of implementation of business style accrual accounting has been limited to a few national governments. This has included Australia, New Zealand and the UK which have been the most fervent adherents of the New Public Management ideology and neo-liberalism more generally (Pollitt \& Bouckaert 2000).

Despite nearly 20 years of experience of business style accrual accounting in the central government of New Zealand and the states of Australia and over a decade in the UK, the proponents of business style 
accrual accounting still rely on claims for its benefits rather than providing objective evidence of the actual experience. This may be because most objective research shows it to be a costly reform which does not deliver the benefits claimed for it.

\section{Defining business style accrual accounting and why public sector is different}

Business style accrual accounting was specifically developed to measure the profit earned by a company in a particular financial year. It does this by matching the cost of the production and provision of goods and services with the revenue gained from their sale. The cost of capital assets (for example, a factory) is spread over their useful life by charging the Profit \& Loss Account with depreciation which is an estimate of the value of the assets used during the year. The residual value of the capital assets is reporting in the Balance Sheet along with any debts the company may have.

"Governments uniquely provide public goods and finance them through taxation... These characteristics sever the link between service delivery and revenue recognition, making it impossible to match revenues and expenses" (Chan 2003, p. 5). As a result the full costs of capital assets are reported by governments in the year in which the associate payments are made. The underlying principle of the cash based system, as developed for and within government, is democratic control over the use of public funds (Pallot 1992).

The unique properties of public sector entities was confirmed by the Government Accounting Standards Board (accounting standard setter for state and local governments in the US) when it stated that:

"Governments are fundamentally different from for-profit business enterprises in several important ways. They have different purposes, processes of generating revenues, stakeholders, budgetary obligations, and propensity for longevity. These differences require separate accounting and financial reporting standards in order to provide information to meet the needs of stakeholders to assess government accountability and to make political, social, and economic decisions" (GASB 2006: 1)

A fundamental objective of the financial statements for any public sector organisation should be to fulfil the stewardship function by providing an audited comparison of the actual use of recourses with the agreed budget. A government's financial accountability arises from the budget setting process during which it gains agreement to the levels of taxation which will be levied and to the funding which will be allocated to the various services which it intends to provide. Thus the budget out-turn report and the associate report of the Auditor General are the prime documents by which governments are held to account by parliament for the regularity and probity of their financial management.

\section{Business style accrual accounting is not new in the public sector}

The use of business style accrual accounting is not a new idea, but only makes sense in the context of the adoption of New Public Management. With this approach, the public sector adopts private sector approaches to financial management including business style accrual accounting.

Birmingham City Council, then the sixth biggest economic entity in Britain, moved to a form of accrual accounting in 1850. This decision was taken as its major activities were the provision of public utilities (gas, electricity, water etc) and so it was considered appropriate for the City to account for its finances in the same way as a private provider (Coombs and Edwards 1996). However, this approach was not accepted for general use across the public sector and the cash basis of reporting was retained by the 
central Treasury (Ministry of Finance) as part of the major financial reforms introduced in 1866. Thus it was the cash basis of accounting which was established in the British colonies across the world over the next 100 years (Wynne, 2007).

Moves to business style accrual accounting in the British central government only really started in 1991 when health trust were established as quasi-independent business entities (Wynne, 2007). At this time this approach was still contested for central government and it was not until the mid-1990's that the move from the cash basis was agreed (Treasury 1995).

Many of the key British government officials responsible for the introduction of accrual accounting only accepted its relevance in the years immediately before they led the reforms. So, for example, Andrew Likierman was able to say, in a book published in 1992 that:

Those who believe that private sector accounts are superior need to bear two factors in mind. First, that there are no immutable accounting or other financial reporting rules which apply irrespective of the nature and purposes of the organisation whose activities and results are being displayed or the objectives of presentation. Second, that cash accounts, despite their crudeness, have a degree of transparency that accrual accounts cannot give and that many private sector financial reports do not seek to offer (page 23).

Similarly, Perrin (1998) explained the view held in the Treasury in the 1970s on accounting for central government funds as follows:

The Treasury view was that accruals accounting involving allocating costs between years on the basis of resource use rather than cash funding was incompatible with Parliamentary sovereignty and therefore unacceptable. Parliament voted cash funding year-on-year, so therefore the main control accounts, reports and accountability must be on an annual cash basis (Perrin, 1998, page 8).

Similarly, in Australia, the use of business style accrual accounting in the public sector is not a new idea. The Postmaster-General's department commenced preparing commercial accounts (including a full profit and loss statement and balance sheet) in 1913, and continued to use this form from that date (Carlin 2003). Again this approach to public sector financial reporting did not gain general currency in the Australian public sector until New Public Management was adopted in recent decades.

So business style accrual accounting was not adopted because of its technical superiority, but because it was considered to be more appropriate within the context of New Public Management. However, the experience of those countries most committed to this approach is that business style accrual accounting does not provide the information that can be used to manage the public sector more efficiently.

\section{United Kingdom}

Despite the objective of the reform being to increase efficiency and to reduce costs, no official study has been undertaken on the costs of introducing business style accrual accounting in Britain (Chow and Humphrey, 2003). However, one indicator of the scale of these costs is the number of professionally qualified accountants employed in central government. This increased from less than 600 in 1989 to 2200 in 2003 (personal communication with HM Treasury), the period in which business style accrual accounting was introduced, and has subsequently increased further. In addition, for example, the 
auditors fees for the UK National Audit Office increased by $67 \%$ with the introduction of accrual accounting in 2001/02 (NAO, 2002).

The National Audit Office has undertaken three studies in this area since the introduction of business style accrual accounting and two academic studies have been undertaken on the costs and benefits of its introduction.

The report of the first National Audit Office study concluded that:

In most cases it is too soon to identify any discernible benefits from better resource management in terms of contributing to improved public services from for example, enhanced efficiency (2003, page 31).

Its second study reported that:

Departments have made significant progress in using accruals-based accounting and budgeting systems since our previous study. This has allowed departments to better understand how they are using their financial resources, for example by offering more detailed information to manage their assets and liabilities. Departments have used this information to help identify under-utilised assets and to dispose of those no longer required. (NAO 2008, paragraph 9, page 7)

So the only specific benefit was that ministries (called departments in the UK) were able to identify and sell assets (mainly buildings) which were no longer used! However, most of the information for such an exercise would have been available in asset registers before the introduction of accrual accounting.

The third National Audit Office study, reporting in March 2011, recognised that business style accrual accounting is now well developed, but clearly indicates that senior managers do not appear to be using the information provided. So the summary of this study reports that:

active management of cash flows and the balance sheet remains generally inadequate across government (page 5).

And:

It remains unusual for departments to have good information on the unit costs of outputs, measures of productivity or the value of outcomes, especially where outcomes cross departmental boundaries (page 8 ).

The detailed report goes on to explain that:

Our financial audit work confirms that the general standard of financial reporting has improved. There is also evidence that departments are gathering information on the working capital aspects of their balance sheets in a more regular and automated way, though they are not generally reporting this information to management or using it to manage the organisation" (page 13).

Both non-executive directors and finance directors told us that, in their view, their Boards did not handle or effectively challenge the financial information presented to them as well as they might. One reason is the complexity of the Government accounting framework (page 17).

In practice, however, the activity of producing annual resource accounts remains largely divorced from financial management within departments. Departments rarely prepare interim resource accounts, and essentially manage their finances based on cash, adjusted for working capital movements. Full resource-based information is created at the year end for Parliamentary 
reporting purposes. Resource information is therefore generally not integrated into, and does not drive, management of departments'business (page 18).

Thus the view of the National Audit Office (UK) is that, after a decade of business style accrual accounting, the approach is now well established, but the additional information available is not being used by senior managers and the accrual accounts (resource accounts) are only produced at the yearend as a legal obligation.

The UK health service is highly capital intensive and so it may be assumed that the move to accrual accounting from 1991 would have provided significant benefits in terms of the more efficient use of these capital assets, for example, hospitals and medical equipment. However, a research report (Mellet, Macniven \& Marriott, 2007), funded by the Scottish Institute of Chartered Accounting, concluded that:

there was no evidence that the perceived benefits from the introduction of... accruals accounting... were being realised

In an article (2008) outlining the results of this study, the authors provided further details, indicating that:

No positive impact on decision making was found. Accounting measures did not influence 'rent or buy' or 'retain or dispose' decisions, although the desire not to take an adverse 'hit to the bottom line' could impede disposal decisions. Similarly, no evidence was found of the opportunity cost of capital expenditure being recognised, as reflected through measures based on resource accounting, this being a matter for active consideration when acquiring or constructing fixed assets (page 7).

This article concluded with the following advice:

Governments which have undertaken to implement accruals accounting should therefore beware of the fact that... any potential benefits may not be realised (page 8).

A second study, funded by the Association of Chartered Certified Accountants (ACCA), reviewed the costs and benefits of adopting accrual accounting in Northern Ireland (NI), a region of the UK (Hyndman and Connolly, 2005). This research concluded that:

there was little evidence that [accrual accounting] information was extensively used in decision making within the NI public sector... Many interviewees identified the problems of unnecessary complexity and incomprehensibility of the information as undermining its potential use (page 7) while no department had prepared a budget for the introduction of [accrual accounting], or kept records of actual costs, the costs were perceived as being substantial (page 7).

\section{Australia}

The message from Australia is similar. In an academic review of international public financial management reforms (Guthrie, Humphrey, Jones and Olson, 2005: page 4) it was noted that "observations of actual outcomes of the NPFM change processes [including accrual accounting] have been limited to those made by the initiators themselves, while formal independent studies of public sector change impact have been rare". 
Another Australian academic has claimed that the "present mode of presentation of the accrual budgets and financial statements of Australian Government departments has become a controversial matter. It has led to widespread dissatisfaction in Parliament and parts of the Public Service" (Barton, 2004).

A former Australian Auditor General commented that "Parliament lost control of Commonwealth financial matters when it agreed to a number of fundamental changes in the reform of the Commonwealth finances" (quoted in MacDonald 2009).

In March 2007, the Australian Senate Finance and Public Administration Committee (Executive Summary: page iv) noted that:

The Committee considers that the adoption of accrual accounting and budgeting has the potential for enhancing the management of the Commonwealth's funding and expenditure and has done so to an extent. Nevertheless, accrual budgeting and especially the associated outcomes and outputs framework, while resulting in some improvements in transparency, have posed challenges for Parliament's control of the appropriations processes.

So a decade after its introduction, Australian parliamentarians are still noting only the 'potential' for accrual accounting. In addition, they complain about its detrimental effect on parliamentary financial control.

\section{New Zealand}

In the case of New Zealand, two academics (Guthrie et al, 2005) concluded that:

various financial mechanisms built on the accrual accounting base have, over the long term, had a detrimental effect on departmental capability in a manner that has escaped parliamentary understanding and control (page 8).

They also argued that this reform "promised significantly more in terms of efficiency, better service, and increased public choice than it delivered in practice" (page 7).

As with the UK and Australia, the introduction of accrual accounting in New Zealand has been accompanied by misunderstandings and confusion. Debits and credits were muddled with fiscal targets and capital expenditure (Ellwood and Newburry, 2007). In addition, there was controversy over the accounting treatment of heritage assets with the regional museums refusing to value their collections nor include the result in their balance sheets (Ellwood and Newberry, 2007).

In both Australia and New Zealand various academics have illustrated how the introduction of business style accrual accounting has facilitated neoliberal ideologies and supported privatization policies. For example, it over-valued the costs of public sector goods and so supported their being contracted out to private sector suppliers that appeared cheaper (Carlin 2003; Elwood \& Newberry 2006; Newberry \& Pallot 2005; Smullen, 2009).

\section{Cayman Islands}

If business style accrual accounting did not provide the benefits expected of it in Australia, New Zealand and the UK, this reform has clearly failed in other countries, for example the Cayman Islands, with an associated loss of financial control. 
In 2008, a special Auditor General report on the State of Financial Accountability Reporting described "a very grim assessment of the state of financial accountability reporting throughout the Cayman Islands Government". The Auditor General found the "current situation deplorable". Furthermore he believed that "the legislative assembly has lost control of the public purse".

In an update report, issued in April 2010, the Auditor General concluded that, "the state of financial accountability reporting has gotten worse in the two years since I last reported on this matter". The financial statements for 2004/05 (the first year of accrual accounting) had still not been issued, despite the Government having spent an additional \$1 million in the current fiscal year to address the problem. The Auditor General assessed the efforts as being "too limited and therefore insufficient to address the situation". He estimated that at the current rate it would be "several years before the accounting activities of the Government are up to date" and considered that this was "unacceptable". The Auditor General concluded his second special report by saying: "I believe this situation has become a national crisis that could lead to tremendous consequences for the Cayman Islands Government if not addressed immediately".

The Cayman Islands has one of the highest per capita incomes in the world and, as it is a tax haven and financial services centre, there are many qualified accountants available locally. If the introduction of accrual accounting can go so horribly wrong in the Cayman Islands, imagine what could happen in other developing countries where business style accrual accounting is still being promoted for the public sector.

\section{Limited adoption}

Despite all the claimed benefits of adopting business style accrual accounting, governments of many of the largest economies in the world have not introduced this reform. This includes the central governments of, for example, China, Germany, Italy, Japan and Russia. Several other governments have reviewed the evidence and decided that accrual accounting is not appropriate (for example, Ghana, Mauritius, Namibia, Netherlands and Pakistan).

In December 2007, Mike Hathorn (then chair of the IPSAS Board) said that only six governments across the world had actually issued financial statements on the full accrual basis (at the FEE Public Sector meeting, Brussels).

In their summary of the extent of adoption of IPSAS, the IPSAS Board list more than 50 countries which have made moves towards adopting IPSAS, but then admit that only five countries have fully adopted accrual accounting in line with their approach:

Governments that already apply full accrual accounting standards and apply accounting standards that are broadly consistent with IPSAS requirements:

$$
\begin{aligned}
& \text { - Australia } \\
& \text { - Canada } \\
& \text { - New Zealand } \\
& \text { - United Kingdom } \\
& \text { - United States of America (2008: page 4). }
\end{aligned}
$$

Research undertaken by the author of this paper in early 2012 determined that the only countries which have actually issued accrual based financial statements for their central government ministries are the 
following seventeen (also showing the date adopted and the standards followed):

- Spain (1989) - national standards (IPSAS from 2011)

- New Zealand (1991) - IFRS

- Australia (1994) - IFRS

- USA (1998) - national standards

- UK (2002) - IFRS

- Canada (2003) - national standards

- Latvia (2003) - national standards

- Estonia (2004) - national standards

- France (2006) - national standards

- Colombia (2006) - national standards

- Romania (2006) - national standards

- Switzerland (2007) - IPSAS

- Denmark 2007) - national standards

- Slovak Republic (2008) - IPSAS

- Lithuania (2009) - national standards

- Czech Republic (2009) - national standards

- Barbados (2012) - national standards.

Many other people are concerned that the claimed benefits of business style accrual accounting are being over-sold especially to the governments of developing or transitional countries. For example, Noel Hepworth, based on his experience in Eastern Europe, concluded that:

To introduce accrual accounting is costly, time consuming and requires a diversion of resources from other activities. It requires a great deal of co-operation from key actors and will need significant changes of substance to the organisation, procedures and responsibilities of managers. As Parliament is also affected because of the changes that will be needed to the cash allocation and budgetary control processes it too will need to be consulted. What is more, accrual accounting provides wide scope for the exercise of judgement and this requires technical knowledge, a disciplined approach and an audit system capable of monitoring how judgement is exercised... For these reasons the introduction of accrual accounting also carries considerable risk (2003, page 42).

\section{Conclusion}

The global economic slowdown coupled with the Arab Spring and widespread protest and revolt is undermining the previously dominant view of the efficiency of the free market and the private sector. Similarly, the failure of business style accrual accounting to deliver on its promises is having a 
demoralising effect on at least some of its previous supporters. There seems to be little doubt among academic commentators that business style accrual accounting has not satisfied the ambitious expectations of its proponents (Smullen 2009, 18).

Business-style accounting practices were not devised for the purpose of maintaining financial control. As the control and safeguarding functions continue to be the prime concern of public finance, then business style accrual accounting should not be considered as an appropriate basis for public sector financial reporting (Newberry 2011). Evidence from the few countries that have adopted business style accrual accounting is that it is a costly reform and that the additional information that it provides is rarely used to manage public sector entities more efficiently and so the benefits claimed for it are not achieved in practice.

In contrast, the cash basis of accounting is a relatively simple, robust and well-tried and tested approach to the accounting for public sector organisations. Its emphasis on financial control and parliamentary accountability ensures that these key objectives are more likely to be achieved. The clarity and simplicity of public sector financial statements are essential to ensure that members of parliament and the general public fully understand the implications of what is being reported.

For public sector financial managers, the current questioning of received wisdoms provides opportunities. Not least of these is the possibility of developing existing public sector accounting systems in ways which recognize the distinctive objectives and nature of the public sector. There is a wealth of existing good practice across the Global South which we can use to refine the financial reporting practices of our governments. This organic approach is more likely to be successful than adopting large scale radical reforms, like business style accrual accounting, which have not proved their value in practice.

\section{References}

Anon, (1993) 'IFAC Public Sector Committee meets in New Zealand', Accountants Journal, Vol 72, Issue 5, 34-37.

Australian Senate Finance and Public Administration Committee (2007) Transparency and accountability of Commonwealth public funding and expenditure, Canberra,

Commonwealth of Australia

http://www.aph.gov.au/SENATE/committee/fapa_ctte/completed_inquiries/2004-

07/funding_expenditure_06/(8 November 2011)

Barton, A. (2004). How to profit from defence: A study in the misapplication of business accounting to the public sector in Australia. Financial Accountability and Management, 20:3, pp. 281-304.

Carlin, TM, (2003) Accrual Accounting \& Financial Reporting in the Public Sector: Reframing the Debate Sydney, Macquarie Graduate School of Management, MGSM WP 2003-22

Chan, J. L. (2003) 'Government Accounting: An Assessment of Theory, Purposes and Standards' Public Money and Management, April 
Chow, D. and Humphrey, C. (2003) 'Whole of Government Accounting: an aide to performance, management and accountability?' 9 $9^{\text {th }}$ CIGAR Conference, Bodo, Norway

Chow D, Humphrey C, Moll J (2008) Whole of Government Accounting in the UK, London, ACCA http://www.accaglobal.com/publicinterest/activities/research/reports/accountability/rr 101 (6 September 2008)

Coombs, H.M and Edwards, J.R. (1996) ‘Accounting Innovation: Municipal Corporations 1835-1935

Duguay, D (2008) Auditor General report on the State of Financial Accountability Reporting (July)

Cayman Islands Government:

http://tinyurl.com/accrualcayman1

Duguay, D (2010) Auditor General report on the State of Financial Accountability Reporting (April) Cayman Islands Government:

http://inyurl.com/accrualcayman2

Ellwood, S and Newberry, S (2007) Public Sector Accrual Accounting: Instituting Neo-liberal Principles? Accounting, Auditing \& Accountability Journal, Vol 20 No 4

Financial Reporting Advisory Board (October 2007) Strengthening Parliament's role on public spending: aligning budgets, estimates and accounts, Financial Reporting Advisory Board Paper, London, HM Treasury

http://www.hm-treasury.gov.uk/media/C/D/frab88_public_spending.pdf (6 September 2008)

Government Accounting Standards Board (GASB, US) (2006), Why Governmental Accounting and Financial Reporting Is — and Should Be-Different http://www.gasb.org/white paper_full.pdf

Government Accounting Standards Board (1987) 'Concepts Statement No.1: Objective of Financial Reporting' GASB

Guthrie, J. (1998) Accrual Accounting in the Australian Public Sector, Financial Accountability and Management, 14 (1) pp 1-19

Guthrie, J. Humphrey, C. Jones, L R. \& Olson, O., (2005), International Public Financial Management Reform, Information Age Publishing, Greenwich, Connecticut

http://tinyurl.com/6c6yaj9 (3 November 2011)

Hepworth, N. (2003) Preconditions for Successful Implementation of Accrual Accounting in Central Government, Public Money \& Management 23(1), pp 37-43 http://www.cipfa.org.uk/international/ download/paper_pmm_hepworth_jan03.pdf(6 September 2008)

Hood, C. (1991), 'A Public Management for all seasons ?', Public Administration, Vol. 69, pp. 3-19. 
Hyndman, N. and Connolly, C. (2005) The impact of introducing resource accounting in Northern Ireland, ACCA, London

http://www.accaglobal.com/publicinterest/activities/research/reports/accountability/rr-087

IPSAS Board (2008) IPSAS Adoption by Governments, July, New York, IFAC

http://web.ifac.org/download/IPSASB_Adoption_Governments.pdf (6 September 2008)

Likierman, A. (1992) Financial Reporting in the Public Sector in Public Sector Accounting and

Financial Control, Edited by Sir Douglas Henley, Clive Holtman, Andrew Likierman and John Perrin, Chapman \& Hall, London

McDonald, C. (2009). Modern budget reform and the impact on parliaments: the Australian experience. Paper presented at the OECD Parliamentary Budgetary Officials first annual meeting (26-27 February 2009).

Mellett, H, Macniven, L, Marriott, N, (2007) NHS Resource Accounting in Wales: Problems of Implementation, ICAS

http://www.icas.org.uk/site/cms/contentviewarticle.asp?article=5232

Mellett, H, Macniven, L, Marriott, N, (2008) Resource Accounting in the Public Sector: Problems of Implementation in International Public Sector Bulletin, 11 February, ACCA, London http://tinyurl.com/66c6fxz

National Audit Office (2011) Progress in Improving Financial Management in Government, NAO, London www.nao.org.uk/publications/0506/progress in_improving_governme.aspx

National Audit Office (2008), Managing Financial Resources to Deliver Better Public Services, London, $\mathrm{NAO}$

http://www.nao.org.uk/publications/nao_reports/07-08/0708240.pdf (6 September 2008)

National Audit Office (December 2003), Managing Resources to Deliver Better Public Services, London, NAO

www.nao.gov.uk/publications/nao_reports/03-04/030461.pdf (6 September 2008)

National Audit Office (2002), Helping the Nation Spend Wisely - Annual Report 2002, London, NAO

Newberry S (2011) The use of accrual accounting in New Zealand Central Government achievements and second thoughts, Rome, Italy, 19th April

Newberry, S., and J. Pallot (2005), 'A wolf in sheep's clothing? Wider consequences of the financial management system of the New Zealand central government', Financial Accountability and Management, Vol. 21, No. 3, pp. 263-277.

OECD (2010) Progress in Public Management in the Middle East and North Africa 
Case Studies on Policy Reform, Paris: OECD Publishing

www.oecdbookshop.org/oecd/display.asp?K=5KS5DM3MS5MX\&LANG=EN

Pallot, J. (1992). Elements of a theoretical framework for public sector accounting. Accounting, Auditing and Accountability 5:1, pp. 38-59.

Perrin, J., (1998) From Cash to Accruals in 25 Years, Public Money and Management, 18 (2), pp. 7-10

Pollitt, C and Bouckaert, G (2004) Public Management Reform: A Comparative Analysis, University Press, Oxford.

Smullen, A (2009) Business Style Accounting for the Core of Government: Academic Debates and International Experience, Report prepared for the Ministry of Finance, The Netherlands, Amsterdam

Treasury (1995) Better Accounting for the Taxpayer's Money: The Government's Proposals for Resource Accounting and Budgeting in Government Cm. 2929, HMSO

Wynne, A. (2008) Accrual accounting - a fad that has had its day?, International Journal of Governmental Financial Management, 2008: Volume VIII, Number 2

$\underline{\mathrm{http}: / / \text { tinyurl.com/ceuj72 }}$

Wynne, A. (2007). Is the Move to Accrual Based Accounting a Real Priority for Public Sector Accounting, Public Fund Digest, Vol. VI, No. 1.

http://www.icgfm.org/documents/Digest_000.pdf 